\title{
STUDY OF AETIOLOGY AND CLINICAL FEATURES OF FEBRILE THROMBOCYTOPENIA
}

\author{
G. Vasavilatha' ${ }^{1}$ N. Ravi Kumar², P. Suresh Kumar ${ }^{3}$
}

${ }^{1}$ Associate Professor, Department of General Medicine, Andhra Medical College, Visakhapatnam.

${ }^{2}$ Senior Resident, Department of General Medicine, Andhra Medical College, Visakhapatnam.

3Junior Resident, Department of General Medicine, Andhra Medical College, Visakhapatnam.

\begin{abstract}
BACKGROUND

Febrile thrombocytopenia is one of the most challenging problems in the field of medicine. Fever with thrombocytopenia is the common manifestation of infective diseases. It helps to narrow the differential diagnosis and management. Treatment of underlying condition will lead to rapid improvement in platelet count and minimise bleeding manifestations and other complications. Hence, there is a need for study to know the aetiology and clinical features of febrile thrombocytopenia.

The aim of this study is to study the aetiology and clinical features of febrile thrombocytopenia.
\end{abstract}

\section{MATERIALS AND METHODS}

50 patients who were admitted with febrile thrombocytopenia over 2 months of period from July $20^{\text {th }}$ to $20^{\text {th }}$ September 2017 in King George Hospital, AMC, Visakhapatnam, were studied retrospectively.

\section{RESULTS}

In this present study, the incidence of febrile thrombocytopenia was more common in male (66\%) as compared to female (34\%). The study reveals that age up to 50 years constituting $78 \%$ of the cases and above 50 years constituting $22 \%$ only. Apart from fever $(100 \%)$ in male patients vomiting $(28 \%)$ and cough $(20 \%)$ were the most common clinical features, while in female patients, body pains $(20 \%)$ and headache (18\%). Bleeding manifestations were more common in males $(18 \%)$ than in females $(10 \%)$. Malaria in 22 cases (44\%) constitutes the most common aetiology of febrile thrombocytopenia of which falciparum 10 (20\%), vivax 8 (16\%) and both $4(8 \%)$ followed by viral infection including dengue in 17 cases (34\%). The present study reveals that severe thrombocytopenia (platelets $\left.<20000 / \mathrm{mm}^{3}\right)$ is present in $18 \%$ of cases, moderate $\left(20000-50000 / \mathrm{mm}^{3}\right)$ in $34 \%$ and mild thrombocytopenia ( $>50000 / \mathrm{mm}^{3}$ ) is present in $48 \%$ of cases. Melena was the most common presenting manifestation followed by petechiae and haematochezia.

\section{CONCLUSION}

Though there is no absolute relation between platelet count and severity of bleeding, the risk of bleeding increases as the platelet levels fall below 20,000/ $\mu \mathrm{L}$. In majority of the cases thrombocytopenia was asymptomatic, but in a significant number of cases bleeding manifestations are seen which require prompt management to prevent life-threatening complications.

\section{KEYWORDS}

Febrile Thrombocytopenia, Aetiology, Malaria, Bleeding Manifestations.

HOW TO CITE THIS ARTICLE: Vasavilatha G, Kumar NR, Kumar PS. Study of aetiology and clinical features of febrile thrombocytopenia. J. Evolution Med. Dent. Sci. 2017;6(87):6025-6029, DOI: 10.14260/jemds/2017/1310

\section{BACKGROUND}

Febrile thrombocytopenia is one of the most challenging problems in the field of medicine. Fever is defined as A.M. temperature more than $98.9^{\circ} \mathrm{F}$ and P.M. temperature more than $99.9^{\circ} \mathrm{F}$. Thrombocytopenia is defined as platelet count less than $1,50,000 / \mu \mathrm{L}$ in blood. ${ }^{1}$ The fall in the platelet count may be due to decreased production, increased splenic sequestration and accelerated destruction.

Thrombocytopenia is characterised by bleeding, most often from small vessels. This can manifest as petechiae over the skin, haemorrhages from mucosa of gastrointestinal and genitourinary tract. Intracranial haemorrhage is a dangerous

'Financial or Other Competing Interest': None.

Submission 28-09-2017, Peer Review 23-10-2017,

Acceptance 25-10-2017, Published 30-10-2017.

Corresponding Author:

Dr. G. Vasavilatha,

W/o. Ch. Avatharamu Naidu,

Type 5/5, Portquarters,

Maharanipeta,

Visakhapatnam-530002, Andhra Pradesh

E-mail: doctorgvlatha@gmail.com

DOI: $10.14260 /$ jemds $/ 2017 / 1310$ consequence in thrombocytopenic patients. ${ }^{2}$ Although, there are many causes for thrombocytopenia, fever is the commonest cause.

Febrile thrombocytopenia is commonly due to malaria, enteric fever, sepsis, leptospirosis, miliary tuberculosis, rickettsial infections, arbovirus such as dengue or yellow fever and human immunodeficiency virus (HIV). Febrile thrombocytopenia helps to narrow the differential diagnosis and management. Finding out the cause of thrombocytopenia is critical to treating the condition.

\section{Aim \\ To study aetiological and clinical features of febrile thrombocytopenia.}

\section{MATERIALS AND METHODS}

Sample was collected retrospectively from cases admitted with febrile thrombocytopenia in King George Hospital, Visakhapatnam over a period of 2 months' time $\left(20^{\text {th }}\right.$ July 2017 to $20^{\text {th }}$ September 2017). Detailed history and clinical examination were noted. Cases were analysed for various parameters like platelet count, $\mathrm{QBC}$, dengue serology, x-ray 
and other lab investigations. Age, sex, duration of stay, severity, complications and mortality were noted.

\section{Inclusion Criteria}

Both sexes aged more than 12 years who were admitted with febrile thrombocytopenia in medical wards during $20^{\text {th }}$ July 2017 to $20^{\text {th }}$ September 2017 were included.

\section{Exclusion Criteria}

Pregnant patients.

- $\quad$ Patients with cirrhosis and chronic liver diseases.

- Diagnosed cases of platelet disorders and dysfunction.

- Patients on antiplatelet therapy.

\section{RESULTS}

\begin{tabular}{|c|c|c|c|}
\hline \multirow{2}{*}{$\begin{array}{c}\text { Age } \\
\text { (in Years) }\end{array}$} & \multicolumn{2}{|c|}{ Gender } & \multirow{2}{*}{$\begin{array}{c}\text { Total } \\
\text { n= 50 }\end{array}$} \\
\cline { 2 - 3 } & Male & Female & $12(24 \%)$ \\
\hline $11-20$ & $8(16 \%)$ & $4(8 \%)$ & $12(18 \%)$ \\
\hline $21-30$ & $8(16 \%)$ & $1(2 \%)$ & $9(24 \%)$ \\
\hline $31-40$ & $8(16 \%)$ & $4(8 \%)$ & $12(6 \%)$ \\
\hline $41-50$ & $3(6 \%)$ & $3(6 \%)$ & $6(12 \%)$ \\
\hline $51-60$ & $4(8 \%)$ & $3(6 \%)$ & $7(14 \%)$ \\
\hline $61-70$ & - & $2(4 \%)$ & $2(4 \%)$ \\
\hline $71-80$ & $2(4 \%)$ & - & $2(4 \%)$ \\
\hline Total & $\mathbf{3 3 ( 6 6 \% )}$ & $\mathbf{1 7}(\mathbf{3 4 \% )}$ & $\mathbf{5 0 ( 1 0 0 \% )}$ \\
\hline
\end{tabular}

\section{Table 1. Distribution of Cases according to Age and Gender}

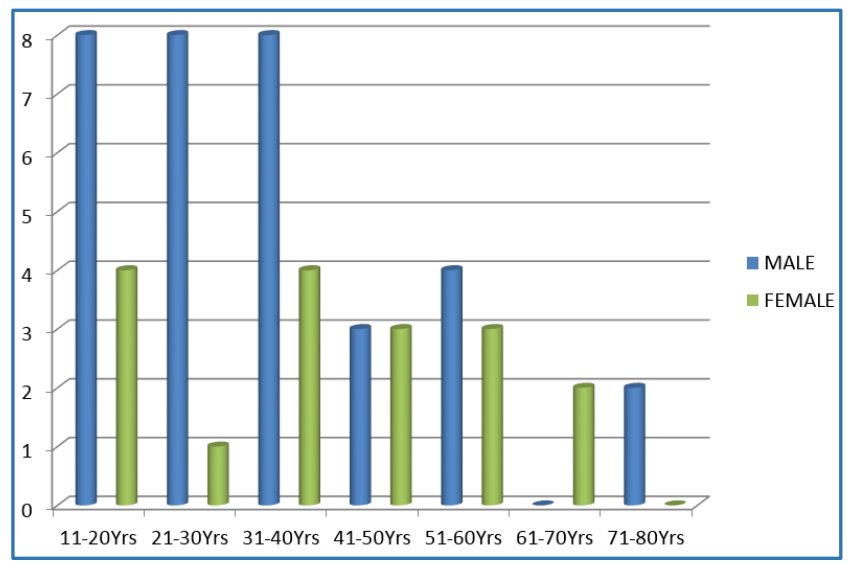

Figure 1. Distribution of Cases according to Age and Gender

In this present study, the incidence of febrile thrombocytopenia was more common in males $(66 \%)$ as compared to females (34\%).

In this study, the highest incidence was found in the age groups of 11 - 20 years and 31 - 40 years (24\%) followed by 21 - 30 years (18\%), then followed by 51 - 60 years (14\%).

The present study reveals that age up to 50 years constitutes $78 \%$ and above 50 years constitutes $22 \%$ (Table 1).

\begin{tabular}{|c|c|c|c|}
\hline \multirow{2}{*}{ Clinical Features } & \multicolumn{2}{|c|}{ Gender } & \multirow{2}{*}{ Total } \\
\cline { 2 - 3 } & $\begin{array}{c}\text { Male } \\
(\mathbf{n = 3 3 )}\end{array}$ & $\begin{array}{c}\text { Female } \\
(\mathbf{n = 1 7 )}\end{array}$ & \\
\hline Fever & $33(66 \%)$ & $17(34 \%)$ & $50(100 \%)$ \\
\hline Vomiting & $14(28 \%)$ & $6(12 \%)$ & $20(40 \%)$ \\
\hline Headache & $8(16 \%)$ & $9(18 \%)$ & $17(34 \%)$ \\
\hline Body Pains & $7(14 \%)$ & $10(20 \%)$ & $17(34 \%)$ \\
\hline Bleeding & $9(18 \%)$ & $5(10 \%)$ & $14(28 \%)$ \\
\hline
\end{tabular}

\begin{tabular}{|c|c|c|c|}
\hline Manifestations & & & \\
\hline Cough & $10(20 \%)$ & $1(2 \%)$ & $11(22 \%)$ \\
\hline SOB & $7(14 \%)$ & $1(2 \%)$ & $8(16 \%)$ \\
\hline Pain Abdomen & $5(10 \%)$ & 0 & $5(10 \%)$ \\
\hline Loose Motions & $4(8 \%)$ & 0 & $4(8 \%)$ \\
\hline Jaundice & $3(6 \%)$ & 0 & $3(6 \%)$ \\
\hline Hypotension & $2(4 \%)$ & $1(2 \%)$ & $3(6 \%)$ \\
\hline $\begin{array}{c}\text { Decreased Urine } \\
\text { Output }\end{array}$ & $1(2 \%)$ & $2(4 \%)$ & $3(6 \%)$ \\
\hline LOC with GTCS & $1(2 \%)$ & $1(2 \%)$ & $2(4 \%)$ \\
\hline \multicolumn{4}{|r|}{ Fable 2. Distribution of Clinical } \\
Features according to Gender \\
\hline
\end{tabular}

Table 2 shows that fever (100\%) was the most common symptom followed by vomiting (40\%), headache (34\%) and body pains $(34 \%)$. While in a prospective cross-sectional observational study conducted by Modi $\mathrm{T}$ et $\mathrm{al}^{3}$ at PDUMC and Civil Hospital, Rajkot, Gujarat, India from 1st November 2014 to 31st March 2016, whereas fever was the most common symptom followed by Headache (49.61\%), Bodyache (36.38\%) and Vomiting (25.69\%).

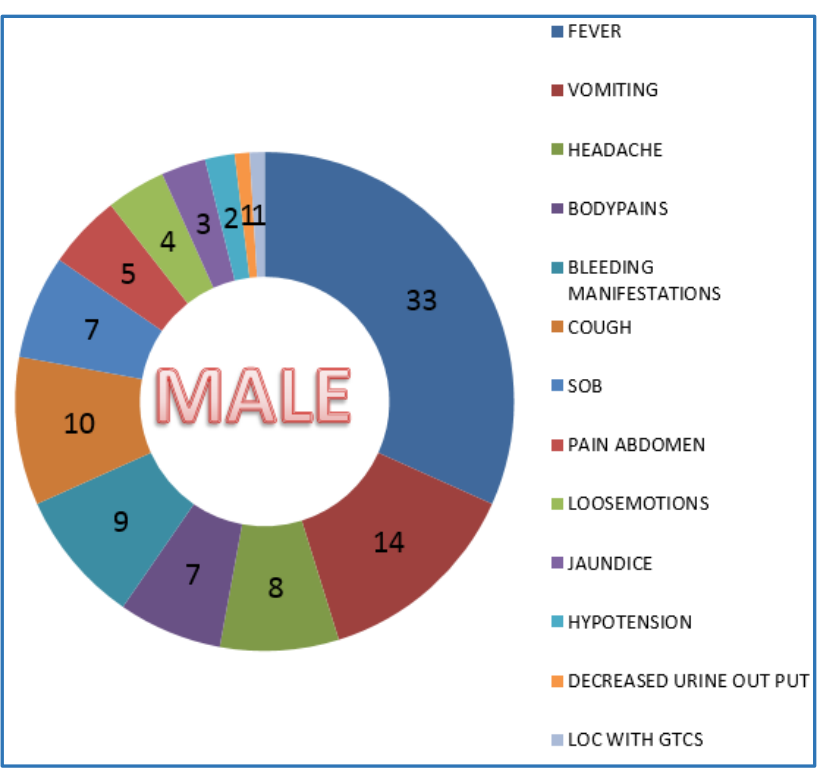

Figure 2a. Distribution of Clinical Features according to Gender

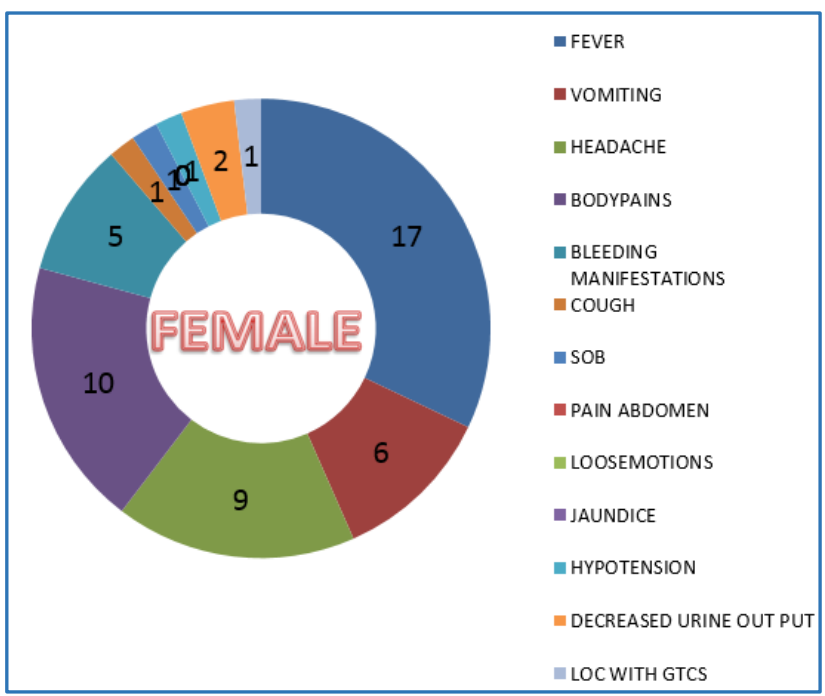

Figure 2b. Distribution of Clinical Features according to Gender 
The study shows that apart from fever (100\%), in male patients vomiting (28\%) and cough (20\%) were the most common clinical features, while in females, body pains (20\%) and headache $(18 \%)$. Bleeding manifestations were more common in males $(18 \%)$ than in females $(10 \%)$. Respiratory symptoms like cough and dyspnoea were commonly seen in male patients.

In this study GIT symptoms like pain abdomen, loose motions and jaundice were present only in males. Nervous system symptoms like loss of consciousness and seizures were equally present in both sexes $(2 \%)$.

\begin{tabular}{|c|c|c|c|}
\hline \multirow{2}{*}{ Aetiology } & \multicolumn{2}{|c|}{ Gender } & \multirow{2}{*}{$\begin{array}{c}\text { Total } \\
(n=50)\end{array}$} \\
\hline & $\begin{array}{c}\text { Male } \\
(n=33)\end{array}$ & $\begin{array}{l}\text { Female } \\
(n=17)\end{array}$ & \\
\hline Falciparum Malaria & $6(12 \%)$ & $4(8 \%)$ & $10(20 \%)$ \\
\hline Dengue Fever & $5(10 \%)$ & $3(6 \%)$ & $8(16 \%)$ \\
\hline Vivax Malaria & $6(12 \%)$ & $2(4 \%)$ & $8(16 \%)$ \\
\hline Mixed Malaria & $2(4 \%)$ & $2(4 \%)$ & $4(8 \%)$ \\
\hline Atypical Pneumonia & $3(6 \%)$ & $1(2 \%)$ & $4(8 \%)$ \\
\hline UTI & $1(2 \%)$ & $1(2 \%)$ & $2(4 \%)$ \\
\hline DSS & 0 & $1(2 \%)$ & $1(2 \%)$ \\
\hline Sepsis & $2(4 \%)$ & 0 & $2(4 \%)$ \\
\hline Enteric Fever & $1(2 \%)$ & 0 & $1(2 \%)$ \\
\hline LL Pneumonia & 0 & $1(2 \%)$ & $1(2 \%)$ \\
\hline Other Viral Fevers & $7(14 \%)$ & $2(4 \%)$ & $9(18 \%)$ \\
\hline \multicolumn{4}{|c|}{ Table 3. Aetiology according to Gender } \\
\hline
\end{tabular}

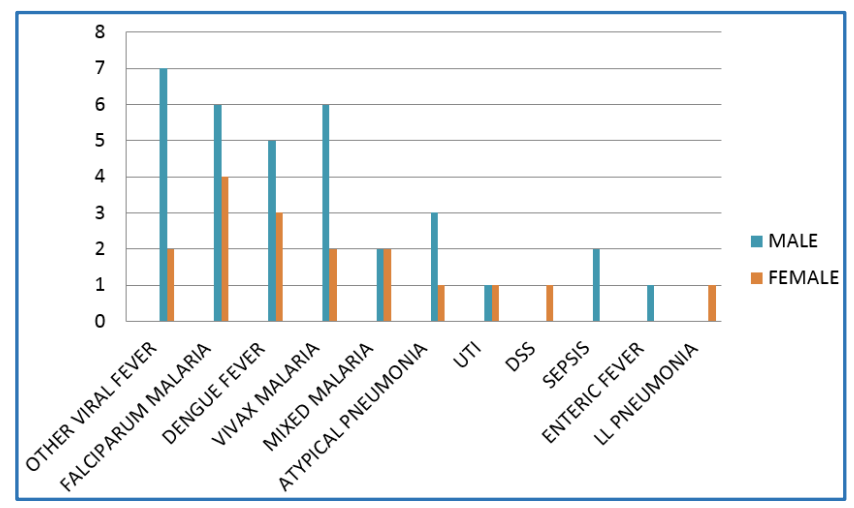

Figure 3a. Aetiology according to Gender

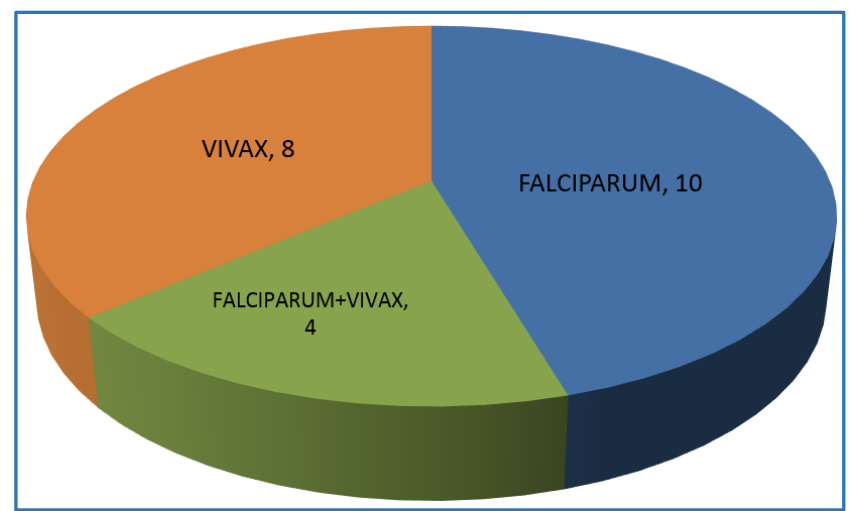

Figure 3b. Types of Malaria Cases with Thrombocytopenia

Malaria in 22 cases (44\%) constitutes the most common aetiology of febrile thrombocytopenia, of which falciparum 10 (20\%), vivax 8 (16\%) and both 4 (8\%) Figure 3b.
Followed by viral infection in 17 cases (34\%), of which 8 cases $(16 \%)$ were of dengue fever and 9 were $(18 \%)$ of viral infection other than dengue.

Other aetiologies are atypical pneumonia $4(8 \%)$, sepsis 2 (4\%) and UTI 2 (4\%), while enteric fever, DSS, lobar pneumonia each constitutes $1(2 \%)$ (Table 3 ).

Similar findings were observed in Gandhi et al study, ${ }^{4}$ had malaria as the major cause of febrile thrombocytopenia. In another study conducted by Lohitashwa et al on 100 patients from March 2004 to September 2005 had similar observations (i.e. malaria being the commonest cause). ${ }^{5}$ Another prospective study, which was conducted on 228 patients with fever and thrombocytopenia in medical unit of Hayatabad Medical Complex during 2008 - 2010 was showing malaria as the commonest cause (53\%), in which 68\% were having falciparum malaria. ${ }^{6}$

While Modi T et al study ${ }^{3}$ and Raikar et al study ${ }^{7}$ had viral aetiology as the major cause of febrile thrombocytopenia.

\begin{tabular}{|c|c|c|c|c|}
\hline \multirow{2}{*}{ Aetiology } & \multicolumn{3}{|c|}{ Platelet Count $\mathbf{~ / \mathbf { m m } ^ { 3 } )}$} & \multirow{2}{*}{ Total } \\
\cline { 2 - 4 } & $<\mathbf{2 0 , 0 0 0}$ & $\begin{array}{c}\mathbf{2 0 , 0 0 0} \\
\mathbf{5 0 , 0 0 0}\end{array}$ & $\mathbf{> 5 0 , 0 0 0}$ & \\
\hline Falciparum Malaria & 3 & 1 & 6 & 10 \\
\hline Dengue Fever & 2 & 3 & 3 & 8 \\
\hline Vivax Malaria & - & 4 & 4 & 8 \\
\hline Mixed Malaria & - & 1 & 3 & 4 \\
\hline Atypical Pneumonia & - & 2 & 2 & 4 \\
\hline UTI & - & - & 2 & 2 \\
\hline RT LL Pneumonia & - & 1 & - & 1 \\
\hline DSS & - & 1 & - & 1 \\
\hline Sepsis & - & - & 2 & 2 \\
\hline Enteric Fever & - & - & 1 & 1 \\
\hline Other Viral Fevers & 4 & 4 & 1 & 9 \\
\hline Total & $\mathbf{9}$ & $\mathbf{1 7}$ & $\mathbf{2 4}$ & $\mathbf{5 0}$ \\
\hline Table 4. Aetiology of Febrile Thrombocytopenia \\
in different Platelet Count \\
\hline \multicolumn{5}{|l}{} \\
\hline
\end{tabular}

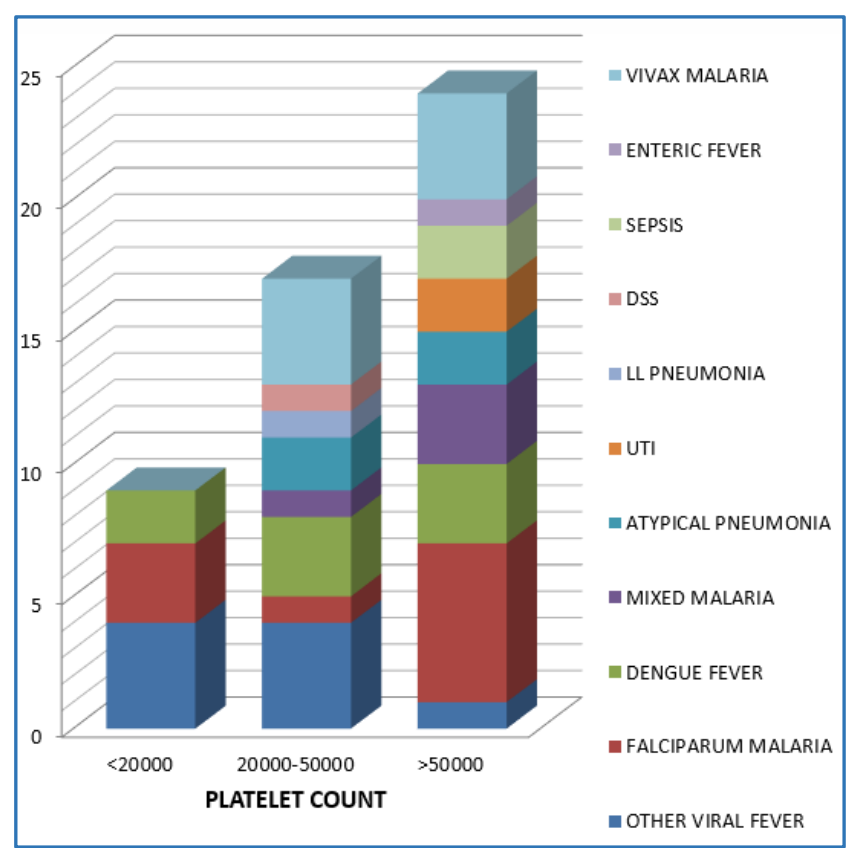

Figure 4. Aetiology of Febrile Thrombocytopenia in different Platelet Count 
Present study reveals that severe thrombocytopenia (Platelet $<20000 / \mathrm{mm}^{3}$ ) is present in $18 \%$ of cases, moderate thrombocytopenia $\left(20000-50000 / \mathrm{mm}^{3}\right)$ in $34 \%$ and mild thrombocytopenia ( $>50000 / \mathrm{mm}^{3}$ ) is present in $48 \%$ of cases. In Praveen Kumar and Kalpana Chandra study, ${ }^{8}$ platelet count was commonly $>50,001 / \mathrm{mm}^{3}(50 \%)$ followed by $20,001 /-50,000 / \mathrm{mm}^{3}(39.47 \%)$ and $<20,000 / \mathrm{mm}^{3}$ in $10.52 \%$ cases. The findings observed in the present study correlate with the above-mentioned study.

Severe thrombocytopenia (18\%) is seen in viral fever (8\%), Falciparum malaria (6\%) and Dengue fever (4\%). Rt. LL pneumonia and DSS are presented with moderate thrombocytopenia only. Mild thrombocytopenia is present in UTI, sepsis and enteric fever (Table 4).

\begin{tabular}{|c|c|c|c|c|}
\hline \multirow{2}{*}{$\begin{array}{c}\text { Bleeding } \\
\text { Manifestations }\end{array}$} & $\begin{array}{c}|c| \\
\mathbf{2 0 , 0 0 0} \\
(\mathbf{n = 9 )}\end{array}$ & $\begin{array}{c}\mathbf{2 0 , 0 0 0 -} \\
\mathbf{5 0 , 0 0 0} \\
(\mathrm{n}=\mathbf{1 7})\end{array}$ & $\begin{array}{c}\mathbf{8 5 0 , 0 0 0} \\
(\mathbf{n = 2 4})\end{array}$ & $\begin{array}{c}\text { Total } \\
(\mathbf{1 4})\end{array}$ \\
\hline Haematochezia & 1 & 2 & - & 3 \\
\hline Melena & - & 3 & 2 & 5 \\
\hline Petechiae & 2 & 1 & - & 3 \\
\hline Haematemesis & - & 1 & - & 1 \\
\hline Haematuria & - & 1 & - & 1 \\
\hline Epistaxis & 1 & - & - & 1 \\
\hline Total & 4 & $\mathbf{8}$ & $\mathbf{2}$ & $\mathbf{1 4}$ \\
\hline Table 5. Distribution of Bleeding Manifestations in \\
different Platelet Count \\
\hline
\end{tabular}

In this study, bleeding manifestations are present in 4 out of $9(44.4 \%)$ cases of severe, 8 out of $17(47 \%)$ cases of moderate and 2 out of $24(8.3 \%)$ of mild thrombocytopenia cases. Melena was the most common presenting manifestation followed by petechiae and haematochezia. Further, it is observed that petechial rash is the most common presentation in severe thrombocytopenia. Gastrointestinal bleeding is more common in this study ( 9 cases) followed by Petechiae (3), Haematuria (1) and Epistaxis (1). Epistaxis is seen in severe thrombocytopenia. Even moderate thrombocytopenia resulted in haematuria, Table 5.

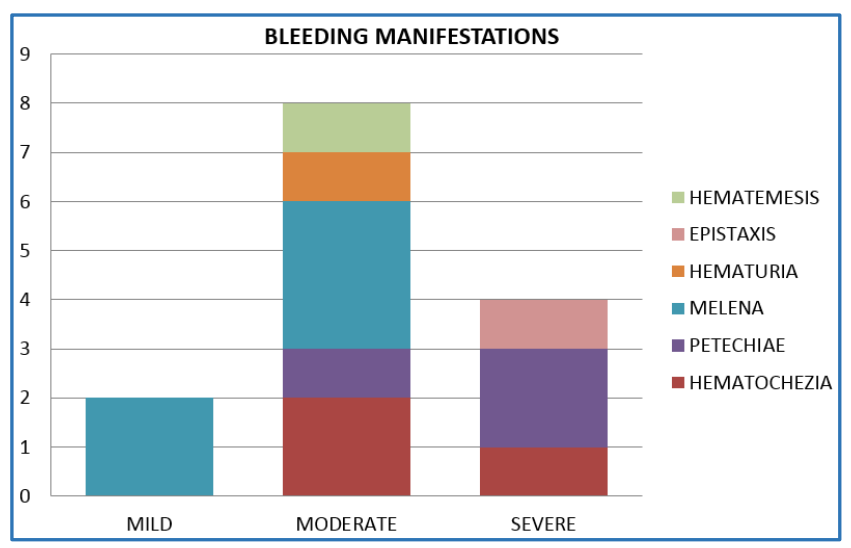

Figure 5a. Distribution of Bleeding Manifestations in Severity of Thrombocytopenia

Present study reveals that clinical manifestations of thrombocytopenia (bleeding manifestations) were noted in
$28 \%$ patients (GI bleed- $18 \%$ patients, petechial rashes- $6 \%$, haematuria- $2 \%$ and epistaxis- $2 \%$ ).

The study conducted by Praveen Kumar and Kalpana Chandra ${ }^{8}$ reveals that the bleeding manifestations were noted in $11.05 \%$ patients and GI bleed was the commonest manifestation. But the study conducted by Lohitashwa et al observed bleeding manifestation in $49 \%$ cases and petechiae was the commonest bleeding manifestation. ${ }^{5}$

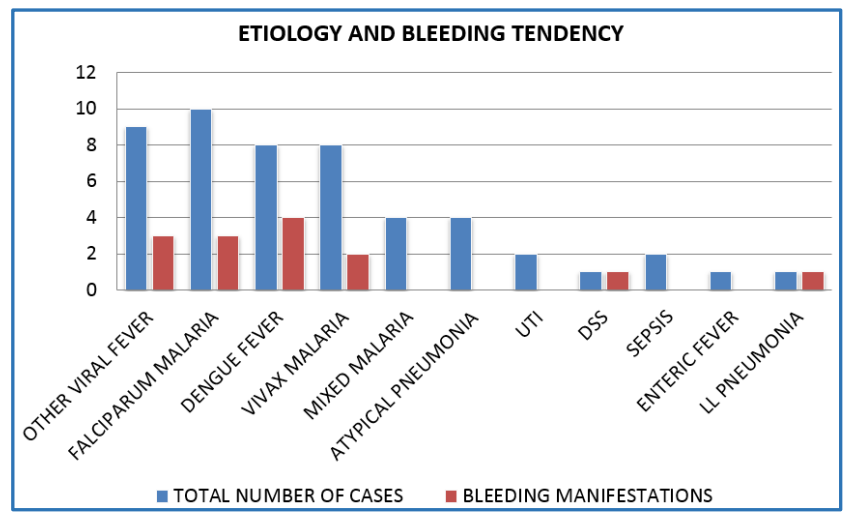

Figure 5b. Distribution of Bleeding Manifestations in different Aetiology

Out of the 8 cases of dengue, 4 (50\%) had bleeding manifestations. Out of the 10 cases of PF malaria, 3 (30\%) had bleeding manifestations. Out of the 8 cases of PV, malaria $2(25 \%)$ had bleeding manifestations. Out of the 9 cases of viral fevers, $3(33.3 \%)$ had bleeding manifestations. In both cases of DSS and pneumonia, 1 out of $1(100 \%)$ had bleeding manifestations.

\begin{tabular}{|c|c|c|}
\hline Recovery & No. of Patients & Percentage \\
\hline Good Recovery & 47 & $94 \%$ \\
\hline Deaths & 3 & $6 \%$ \\
\hline \multicolumn{3}{|c|}{ Table 6. Outcome } \\
\hline
\end{tabular}

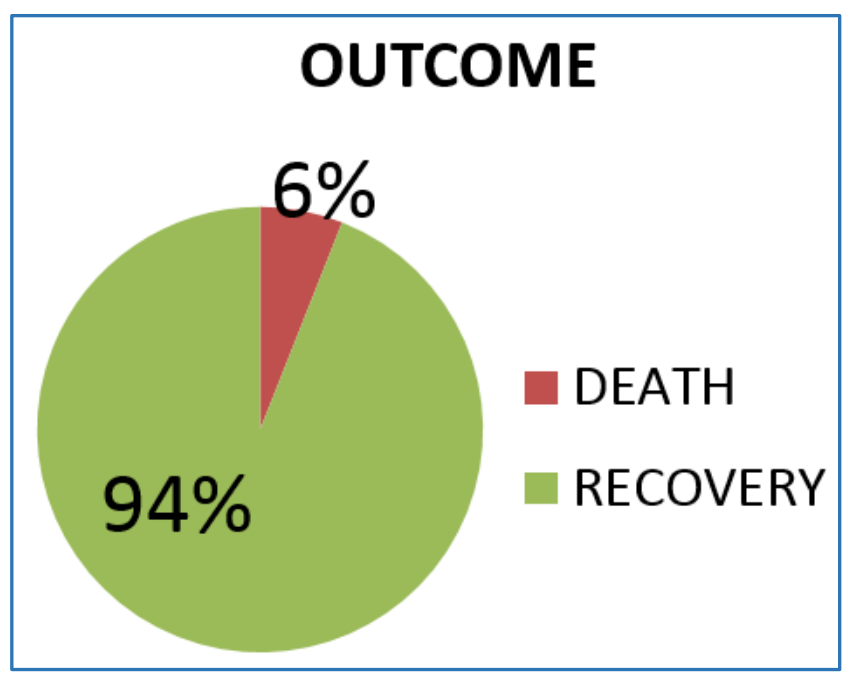

Figure 6. Outcome

In this study 3 cases out of 50 had mortality due to sepsis, viral fever and vivax malaria. All the cases had mild thrombocytopenia only, Table 6 . 


\section{DISCUSSION}

Infections cause decrease in platelet count due to effects on both platelet production and platelet survival. ${ }^{9}$ Geographic, seasonal and endemicity of infectious disease has a major impact on aetiology of febrile thrombocytopenia.

In this study, more incidence is found in the age up to 50 yrs. (78\%) than age above 50 yrs. (22\%). The highest incidence was found in the age groups 11 - 20 yrs. and 31 - 40 yrs. (24\%). Incidence of febrile thrombocytopenia was more common in male (66\%) as compared to female (34\%). The reason for this increased incidence in males may be due to the prolonged outdoor activities and thereby increased chance of exposure to mosquito bites. Bleeding manifestations were seen only in $28 \%$ cases, indicates in the majority of cases thrombocytopenia is asymptomatic.

Malaria is the most common (44\%) aetiology of febrile thrombocytopenia, out of which falciparum 10 (20\%), vivax 8 (16\%) and both 4 (8\%). Thrombocytopenia during malarial infection may appear even before fever, anaemia and splenomegaly become manifest. Immune-mediated lysis, sequestration in the spleen and a dyspoietic process in marrow with diminished platelet production have all been postulated. During early stages of malaria, platelet agglutination as a result of endothelial cell activation and release of activated von Willebrand factor occurs, which may cause thrombocytopenia. ${ }^{10}$

Viral infection $34 \%$ constitutes the second most common aetiology, of which $16 \%$ were of dengue fever and $18 \%$ were of viral infection other than dengue.

Viruses produce thrombocytopenia by various mechanisms like impaired platelet production as a result of direct viral invasion, toxic effect of viral proteins on thrombopoiesis, virus-induced hemophagocytosis and increased platelet destruction by binding of virus-induced autoantibodies or viral antigen-antibody complexes. ${ }^{11}$ Thrombocytopenia in Dengue fever is caused by bone marrow suppression (i.e. decreased platelet synthesis and increased immune-mediated destruction of platelets). ${ }^{12}$

In this study bleeding manifestations are present in $44.4 \%$ cases of severe thrombocytopenia, $47 \%$ in moderate and $8.3 \%$ in mild thrombocytopenia cases. It reveals that there is no absolute relation between bleeding and platelet count. Gastrointestinal bleeding is the most common presentation in this study and petechial rash in severe thrombocytopenia; $50 \%$ of dengue cases, $30 \%$ of PF malaria cases, $25 \%$ of PV malaria cases and $33.3 \%$ of viral fevers had bleeding manifestations. DSS and pneumonia, they themselves were presented with bleeding manifestations.

Mortality was present in mild thrombocytopenia cases. Hence, thrombocytopenia has no correlation to mortality.

\section{CONCLUSION}

1. Febrile thrombocytopenia is more common in males.

2. $78 \%$ cases were seen in the age group below 50 years.
3. The most common aetiology is malaria followed by viral infection.

4. Though there is no absolute relation between platelet count and severity of bleeding, the risk of bleeding increases as the platelet levels fall below $20,000 / \mu \mathrm{L}$.

5. In the majority of cases thrombocytopenia was asymptomatic, but in a significant number of cases bleeding manifestations are seen which require prompt management to prevent life-threatening complications.

\section{REFERENCES}

[1] Konkle B. Harrison's principles of internal medicine. $18^{\text {th }}$ edn. Vol 1, Sec 3, chapter 115-disorders of platelets and vessel wall, pp 965-6.

[2] Gondhali MP, Vethekar M, Bhangale D, et al. Clinical assessment of fever with thrombocytopenia-a prospective study. Int $\mathrm{J}$ Med Res Health Sci 2016;5(1):258-77.

[3] Modi TN, Mehta AD, Sriram AS. Clinical Profile of febrile thrombocytopenia: a hospital-based crosssectional study. J Res Med Den Sci 2016;4(2):115-20.

[4] Gandhi AA, Akholkar PJ. National Journal of Medical Research 2015;5(1):43-6.

[5] Lohitashwa SB, Vishwanath BM, Srinivas G. Clinical and lab profile of fever with thrombocytopenia. Abstract Free Paper Oral Presentation - APICON 2008. Available at: http://www.japi.org/march_2009/oral_presen tation

[6] Khan SJ, Abbass Y, Marwat MA. Thrombocytopenia as an indicator of malaria in adult population. Malar Res Treat Article ID 405981, 2012;2012:pp 4.

[7] Raikar SR, Kamdar PK, Dabhi AS. Clinical and laboratory evaluation of patients with fever with thrombocytopenia. Indian Journal of Clinical Practice 2013;24(4):360-3.

[8] Kumar P, Chandra K. A clinical study of febrile thrombocytopenia: a hospital-based retrospective study. Indian Journal of Clinical Practice 2014;24(10):952-7.

[9] Agarwal M, Rodgers GM. Miscellaneous causes of thrombocytopenia in Wintrobe's clinical hematology. $13^{\text {th }}$ edn. Greer JP, Arber DA, Glader B, et al. 2014:1097-105.

[10] de Mast Q, Groot E, Lenting PJ, et al. Thrombocytopenia and release of activated von Willebrand factor during early Plasmodium falciparum malaria. J Infect Dis 2007;196(4):622-8.

[11] Parikh F. Infections and thrombocytopenia. J Assoc Physicians India 2016;64(2):11-2.

[12] Jayashree K, Manasa GC, Pallavi P, et al. Evaluation of platelets as predictive parameters in dengue fever. Indian J Hematol Blood Transfus 2011;27(3):127-30. 